\title{
Development and Reform Research on College English Pedagogical Mode in New Media Context
}

\author{
Huanhuan Ren ${ }^{1, a}$, Chi Ma ${ }^{2, b}$ \\ ${ }^{1}$ Teaching and Research Institute of Foreign Languages, Bohai University, Jinzhou, 121013, China \\ ${ }^{2}$ Jinzhou Institute of Forestry Research, Jinzhou Forestry Bureau, Jinzhou, 121013, China \\ a email: renhuanhuan2014@163.com, bemail: machi2014@tom.com
}

Keywords: Development; Reform; College English Pedagogical Mode; New Media

\begin{abstract}
As the emerging technologies of new media are drawing more eyeballs, people of all ages and backgrounds are using new media tools for reaching a wealth of information and connecting with people in the world. To be in a better position to adapt to the technology shift from old media to new media, college English instructors should completely re-think how to do the job they've done a certain way for years. The holistic influence of new media technologies on college English pedagogical mode could be interpreted and analyzed from both top-down and bottom-up perspectives. Furthermore, it's suggested that the use of new media in college English pedagogy should be made prior to class, during class, and after class, so that development and reform of Chinese college English pedagogical mode can be ultimately fostered and achieved in new media context.
\end{abstract}

\section{Introduction}

As the emerging technologies of new media are drawing more eyeballs, people of all ages and backgrounds are using new media tools for reaching a wealth of information and connecting with people in the world. It's found that the interactive capabilities of new media can be exploited in a meaningful way in education scenarios. We attempt to exam the basics of new media, get a better understanding of its influence on college English pedagogical mode, and finally obtain instructions on using specific tools in Chinese new media context. Simply stated, the paper aims at addressing how students learn best through the magic of new media technologies, so as to engage people in foreign language learning process and increase choice and autonomy of foreign language learners in college English learning. It's hoped that development and reform of Chinese college English pedagogical mode in new media context can be fostered through incorporating new media technologies into traditional classroom teaching.

\section{Review of the Revolution of New Media}

Pitfalls of old media. What is media? Media is the collective communication outlets or tools that are used to store and deliver information or data. It is either associated with communication media, or the specialized mass media communication businesses[1]. In the past years, when one is asked about "media", there were really only three possible things being discussed: television, print (newspapers and magazines) and radio. Old world media feature strictly one way communications, and static representations of text and graphics. The content provider sends information to the reader and there is no mechanism for a flow of information in the opposite direction. It's a passive process and is geographically limited (e.g. radio and TV stations can only broadcast so far). Along with this, providers have detailed and exact control of what the reader sees or hears [2]. Although some argue that the old media have lost because their capacity to report is a fraction of what it was, some still confirm that old world media dominates, by and large, in the new media world as the people doing the best "new media" work are the old media.

The rise of new media. The phrase new media is in relation to old media forms. With the arrival of the Internet, the term of "media" is used in a much broader, looser context, and things 
that would have never been considered "media" in the past are at the forefront of how we consume information. Logan sees new media as a term that will in general refer to those digital media that are interactive, incorporate two-way communication, and involve some form of computing as opposed to "old media”[3]. In Webopedia, new media is used to describe content made available using different forms of electronic communication made possible through the use of computer technology. The content provided by new media is available on-demand through the Internet and can be viewed on any device regardless of geographical constrains. Providers can not control exactly what the consumer sees, as the medium is provided by the viewer and the message is provided by the creator[4]. It's an active process as the communication is inherently two- way. It's convinced that new media is going to be a disruptive force that would wreak havoc in legacy media.

Media technologies for future development. The topic of new media have grown in popularity and is certainly gaining momentum. Too often we are seeing people are using latest technologies for communication, but it's anticipated that the new media technologies never stop here. With the advent and advance of mobile and wireless technologies, people are provided opportunities to completely or partially get involved in Internet wherever they are, e.g. at home, through computers, or via a phone. The evident is overwhelming that new media in future will take the form of any object in daily life as a mini computing system is successfully embedded in it. The ubiquitous computing technologies which targeted for being pervasive is about changing everything we are face with the physical world. And it represents the next step in the field of new media. In a word, as new media tools and technologies thrive and multiply, they have reshaped or rather continue to reshape the life of everyone across the world.

\section{The Holistic Influence of New Media on College English Pedagogical Mode in China}

Top-down influence of new media. With a view to keeping up with the new developments of higher education in China, deepening teaching reform, improving teaching quality, and meeting the needs of the country and society for qualified personnel in the new era, College English Curriculum Requirements, one requirement of which is to remold the existing unitary teacher-centered pattern of language teaching, was drawn up by Ministry of Education of the People's Republic of China in 2007[5]. Since then, the Requirements serves as guidelines for college English instruction to non-English major students in colleges and universities across China. In it, six aspects of college English curriculum are specified, consisting character and objectives of college English, teaching requirements, course design, teaching model, evaluation and teaching administration. It's suggested that "the extensive use of advanced information technology should be encouraged, computer- and Web-based courses should be developed, and students should be provided with favorable environment and facilities for language learning.”[6]. In brief, colleges and universities are suggested to follow the guidelines of the Requirements and the goals of college English teaching through designing sound college English course systems and incorporating various teaching models and approaches.

Bottom-up influence of new media. Nothing is more common than learners utilizing the Internet and World Wide Web for obtaining target information content or connecting with other people, and it is no more new the overwhelming effect of new media on educational industry. The myriad of new media (e.g. social networks, text messaging, blogs, wikis, virtual worlds, etc.) are increasingly leveraged by college English language learners as new media can provides way for language learners to interact with the content in real-time with the inclusion of user comments and making it easy for learners to share the content online and in social with friends and teachers. Particularly, college English learners are more likely to explore a Web-based listening and speaking learning that suits their own needs in line with their own conditions and students' English proficiency. Instant messaging, interactive blogs, and online forums have been quite popular for them and the rate of usage around the world is increasing rapidly. Besides, college English students learning English through downloading English music, movies, and TV shows that allow them to get exposure to different accents and expressions from around the world. In brief, it's argued that new media technologies and some not-so-new technologies can help learners develop English language skills, 
as learners are given the freedom to access to a wealth of resources and take control of their own learning.

\section{Development and Reform of Chinese College English Pedagogical Mode in New Media Context}

Simply stated, development and reform of Chinese college English pedagogical mode in new media context can be carried out from two aspects, namely the use of new media for college English pedagogy in pre-classroom setting, the use of new media for college English pedagogy in classroom setting, and the use of new media for college English pedagogy in post-classroom setting,, as shown in Fig. 1. The three directions can make the pedagogical mode more comprehensive and more conducive.

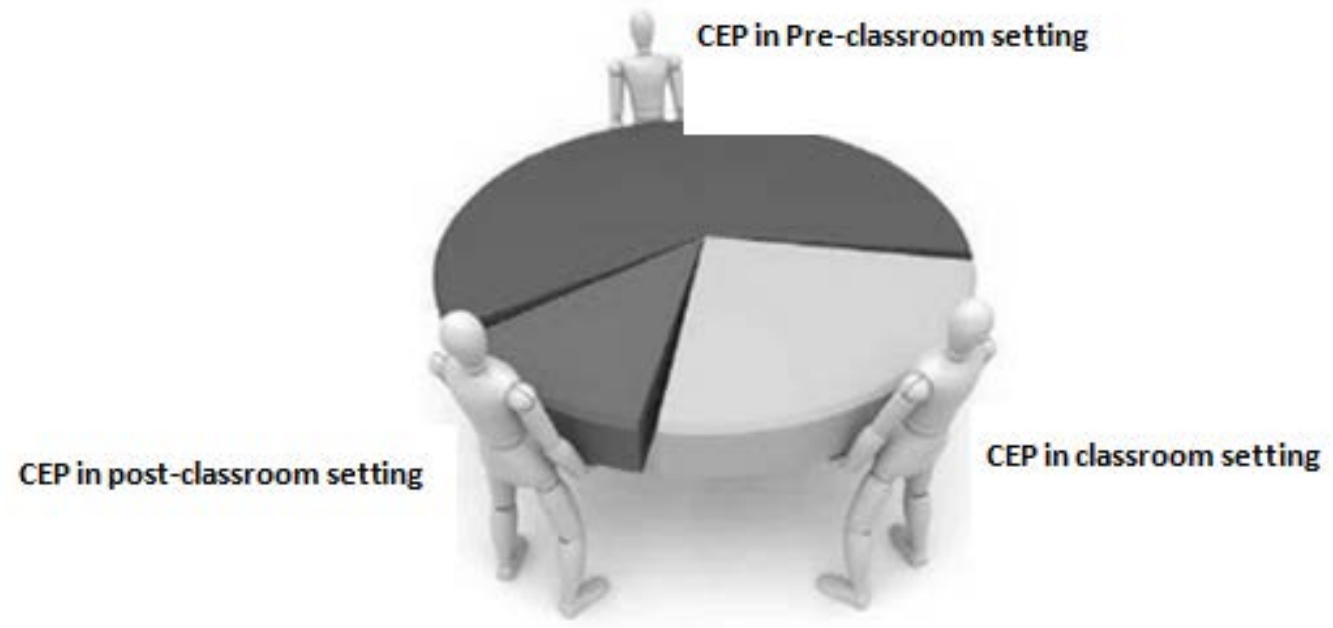

Fig.1. College English pedagogy (CEP) in new media context

The use of new media for college English pedagogy in pre-classroom setting. A few things may come easily to learners but learner autonomy arrives after effort, and good learners are willing to put in the time to learn before coming to classroom. The idea behind college English pedagogy in pre-classroom setting is the actualization of the theory of flipped classroom in new media context. The "flipped classroom" was being discussed everywhere in educational scenario. In this model of instruction, students are expected to gain first exposure to new material prior to class, usually via recorded videos. For students to be successful on their own, videos used in pre-classroom setting must include a variety of approaches in the same way a face-to-face lesson would. Moreover, these videos must also match the curriculum, standards and the activities the students will complete in class. In this regard, majority of the work is expected be completed online with the aid of new media technologies in pre-classroom setting. It has to be noted, however, that the work has to be done in pre-classroom setting is not a synonym for online videos, but rather it's about the learning supported by enabling technologies. Other virtual environments can be also used to develop language skills through fostering easy collaboration among college English learners. In sum, through fully employing modern information technology, college language instructors and learners should move toward a pre-classroom college English pedagogy as it can really individualize student learning and engage learners into an enjoyable hobby outside of the school day.

The use of new media for college English pedagogy in classroom setting. There is some truth about the idea that it is the interaction and the meaningful learning activities that occur during the face-to-face time that is most important, so there is a great need for college English pedagogy in classroom setting. As Bloom observes, students are doing the lower levels of cognitive work (gaining knowledge and comprehension) outside of class, and focusing on the higher forms of cognitive work (application, analysis, synthesis, and evaluation) in class, where they have the support of their peers and instructor[7]. In other words, the harder work of assimilating knowledge should be done by learners in class time, perhaps through problem-solving, discussion, or debates. The promise of new media technologies will not replace the teacher as a whole. The argument goes 
that learners can spend class time working through any gaps or misunderstandings around the content with the teacher acting as guide on the side. In this regard, the role played by teacher alter a lot as "first exposure" doesn't occur via lecture in class. It is motivating teachers to bring technology into their classrooms for productive feedback through the processing activities. The gist, in somewhat simpler terms, is that it's about moving toward a more active learning outside of the classroom, so that more class time is available for interactive, creative and hands-on learning. In a word, this model gives play to the advantages of traditional classroom teaching through incorporating discussions and hands-on activities that occur during class.

The use of new media for college English pedagogy in post-classroom setting. Despite the fact that students don't all learn at the same pace and in the same ways, the benefits of college English learning may accrue from furthering learning in post-classroom setting. More things can be touched or discussed about what have already been learned during classroom and learners are given more opportunities to work directly with students and teachers through the use of new media technologies. Language learners have more power over the way and process by which they study and learn. For instance, if a student really struggled with a concept (e.g. a language point) or missed one thing the professor had said in classroom, he can get the easy access to the content for a second viewing to better understand it, reach for more people to tackle with the problem, or engage in a few of discussions offline and online. It's particularly true for students who want to catch up on missed lessons, as they can watch the videos and online courses at any time and at any place, and check what their groups members did while they were gone. The college English pedagogy in post-classroom setting is centered around the student, not the teacher. New media technologies can allow students to show their mastery of content the way they prefer and become better at taking the lead on finding valuable resources and pursuing learning their own way. All in all, college English pedagogy in post-classroom setting should be directed by learners at their pace, and teachers are expected to give feedback in real time so that active learning can be ultimately met with technology in post-classroom setting.

\section{Conclusion}

Fundamental shifts in education domain occur as the ever changing media and communications technologies are applied into some disciplines, notably within the humanities. To be in a better position to adapt to the technology shift from old media to new media, college English instructors should completely re-think how to do the job they've done a certain way for years. The holistic influence of new media technologies on college English pedagogical mode could be interpreted and analyzed from both top-down and bottom-up perspectives. It's suggested that the use of new media in college English pedagogy should be made prior to class, during class, and after class, in hope that development and reform of college English pedagogical mode can be fostered and achieved in response to various styles and needs of Chinese college English learners in new media context.

\section{Acknowledgement}

This work is part of the project of On Cultivating and Developing Liaoning Scientific Foreign Language Talents with View to Bourdieu' Theory, the project of On Establishing Generative Mechanism of EFL Autonomous Learning Behaviors and Strengthening Development of Learning Field in Ubiquitous Learning Space, and the project of On Constructing Mechanism and Strategies for College English Autonomous Learning Abilities via Mobile Multimedia. This research was supported by the fund of Liaoning Planning of Philosophy and Social Science (Project No. L16CYY001), the fund of Liaoning Provincial Federation Social Science Circles (Project No. 2017lslktyb-019), and the fund of the Thirteenth Five-Year Plan of Education Sciences of Liaoning Province (Project No. JG16DB013). 


\section{References}

[1] Retrieved from https://en.wikipedia.org/wiki/Media.

[2][4] Old Media, New Media, Agincourt Computing, http://www.aginc.net/media.htm, 2004.

[3] Logan, R. K. Understanding New Media: Extending Marshall McLuhan. Retrieved from http://www.peterlang.com/download/extract, 2010.

[5][6] Ministry of Education of the People's Republic of China, College English Curriculum Requirements. Beijing: Higher Education Press, 2007.

[7] Anderson, L. W., \& Krathwohl, D. R., A Taxonomy for Learning, Teaching, and Assessing: A Revision of Bloom's Taxonomy of Educational Objectives. New York: Longman, 2001. 